\title{
Взаимосвязь активности сетей покоя мозга с динамикой риска депрессии и уровня тревожности у трудовых мигрантов в приполярных районах Якутии
}

\author{
Заварзин Е. ${ }^{1 *}$, Таможников С. ${ }^{2}$, Милахина Н. ${ }^{3}$, Борисова Н. ${ }^{4}$, Афанасьева Е. ${ }^{4}$, Никонов Н. ${ }^{5}$, \\ Чикачева С. ${ }^{5}$, Савостьянов А. ${ }^{1,2,3}$ \\ ${ }^{1}$ Новосибирский государственный университет, ЛБМСПЧ ГИ, Новосибирск, Россия \\ ${ }^{2}$ НИИ Физиологии и фундаментальной медищины, Новосибирск, Россия \\ ${ }^{3}$ Институт ицитологии и генетики СО РАН, Новосибирск, Россия \\ ${ }^{4}$ Северо-восточный федеральный университет им. М.К. Аммосова, Якутск, Россия \\ ${ }^{5}$ Якутский медицинский колледж, п. Хандыга, Республика Саха, Россия \\ *e-mail: zavarzinevg@gmail.com
}

Ключевые слова: ЭЭГ, ВDI, TA, функциональная коннективность, функциональные сети мозга

Мотивация и иели: ЭЭГ является относительно дешевым и мобильным средством изучения функциональной деятельности мозга. ЭЭГ, в частности, можно применять для обнаружения нейрофизиологических маркеров депрессивных расстройств и тревожности. В данном исследовании проведен поиск ассоциаций между ЭЭГ маркеры, отражающими функциональную активность сетей покоя мозга, с психологическими показателями, отражающими риск появления тревожно-депрессивных расстройств у трудовых мигрантов на территории Якутии. Цель: оценить взаимосвязь между состоянием сетей покоя мозга и изменением связанных с депрессией психологических показателей, наблюдавшихся в процессе адаптации к жизни в приполярном регионе.

Meтоды и алгоритмы: В обследовании приняло участие 50 здоровых мужчин, приехавших на учебу в Якутию из южных регионов, а также 50 здоровых студентов Медицинского колледжа в п. Хандыга. Каждый мигрант обследовался дважды - сразу же после переезда и через полгода после переезда. Регистрация ЭЭГ проведена в течение 12 минут без функциональной нагрузки. После записи ЭЭГ испытуемые заполняли комплект психологических опросников, включающий опросники на оценку уровня тревожности (тест Спилбергера, личностный профиль Айзенга) и тесты для оценки риска появления депрессии (методики Бека и Ахенбаха). Для анализа коннективности использовалась библиотека SPM, которая по ЭЭГ позволяла реконструировать источники сигнала и создавать маски связности функциональных систем мозга.

Результаты: Показано, что адаптация к якутскому климату сопровождается снижением тревожности у всех испытуемых, что сопровождается снижением мощности в диапазонах дельта и гамма ритма в медиальной коре. Уровень депрессивности у части мигрантов снижался, а у части повышался, что достоверно зависело от таких психологических маркеров как индивидуализм и коллективизм.

Кроме того, на ЭЭГ выявлено снижение степени коннективности дефолт-системы в процессе адаптации, что также коррелировало с показателями тревожности и депрессивности.

Заключение: ЭЭГ маркеры функциональных сетей мозга отражают динамику изменений связанных с депрессией психологических показателей в процессе адаптации мигрантов к приполярному климату. 